(๑) Entomologica Fennica. 8 January 1998

\title{
Water striders (Heteroptera, Gerridae) as bioindicators of heavy metal pollution
}

\author{
Matti Nummelin, Martin Lodenius \& Esa Tulisalo
}

Nummelin, M., Lodenius, M. \& Tulisalo, E. 1998: Water striders (Heteroptera: Gerridae) as bioindicators of heavy metal pollution. - Entomol. Fennica 8: 185-191.

Heavy metal contents of water striders collected near a steel factory and from control sites were analyzed by AAS. The average concentrations $\mu \mathrm{g} / \mathrm{g}$ of dry weight found near the factory vs. the control areas were: A1 76, 65; Fe 840, 330; Mn 49, 37; Zn 310, 280; Cu 44, 42; Cd 1.6, 6.5, respectively. In most cases $\mathrm{Ni}$ and $\mathrm{Pb}$ concentrations were below the determination limit in both sites. There were significant differences between sites in the concentrations of iron and cadmium. Fifth instar larvae had higher iron content than adults, but sexes did not differ in heavy metal content. There were also significant differences between different water strider species as accumulators of zinc, aluminium and cadmium. It is concluded that water striders seem suitable as bioindicators of heavy metals.

Matti Nummelin, Department of Ecology and Systematics, P. O. Box 7, FIN00014 University of Helsinki, Finland; e-mail Matti.Nummelin@Helsinki.FI Martin Lodenius \& Esa Tulisalo, Department of Limnology and Environmental Protection, P. O. Box 27, FIN-00014 University of Helsinki, Finland; e-mail Martin.Lodenius@Helsinki.FI

Received 1 April 1996, accepted 12 August 1996

\section{Introduction}

Several types of organisms have been used as biomonitors of air pollution by heavy metals (e.g. Steinnes 1989). In this study, we test the suitability of water striders (Heteroptera: Gerridae) as heavy metal bioindicators around a well-studied iron and steel factory in Southern Finland (e.g. Monni \& Mäkinen 1995).

High concentrations of cadmium have been reported from Finland in Formicidae-ants $(4-7 \mu \mathrm{g} / \mathrm{g}$ ) (Ylä-Mononen et al. 1989) and from spiders (2$8 \mu \mathrm{g} / \mathrm{g}$ ) (Nuorteva et al. 1992). Many aquatic invertebrates may accumulate cadmium and other heavy metals and they are relatively insensitive to these heavy metals (Spehar et al. 1978).
However, insects are fairly little used as bioindicators of heavy metal pollution (see e.g. Spehar et al. 1978, Rao \& Saxena 1981, Luther 1993). Individuals of many species are not easy to collect in quantities large enough or there is short seasonal supply. Often their origin is unknown due to their flying ability. In many cases also a taxonomic expert is needed to determine the species.

Water striders overcome many of the abovementioned problems: They are predators/scavengers (Jamieson \& Scudder 1977) and thus prone to bioaccumulation. They are often easy to collect in large quantities and species determination is fairly easy on species level (e.g. Vepsäläinen \& Krajewski 1986). Even the winged individuals do not disperse for long distances (Fairbairn 1986). 
Previous studies have shown that ocean-dwelling pleuston gerrids, sea-skaters (Halobates spp.) are suitable bioindicators for cadmium distribution in oceanic surface waters (Cheng et al. 1984, Schulz-Baldes 1989). Sea-skaters are able to concentrate cadmium to their tissues (Schulz-Baldes \& Cheng 1979) and high concentrations of cadmium have been measured in sea-skaters from tropical oceans (Cheng et al. 1976, Bull et al. 1977).

The aim of this study is to screen several common water strider species in southern Finland and their developmental stages from a well-studied area polluted by heavy metals and from a control area in order to assess the suitability of water striders for heavy metal bioindictors.

\section{Material and methods}

\subsection{Species studied}

Gerrids have one and a partial second generation during one summer in southem Finland. Overwintered adults are common during May and June. Newborn adults are common during August (see e.g. Vepsäläinen 1974).

G. argentatus Schumm. (body length $6.5-8 \mathrm{~mm}$, sizes according to Linnavuori 1966) is the smallest Finnish water strider species, G. odontogaster (Zett.) $(7-8.5 \mathrm{~mm})$ and G. lateralis Schumm. (9-11 mm) are medium sized Finnish water striders, and G. thoracicus Schumm. (10-11.5 mm) is somewhat bigger than the two last-mentioned species. Vepsäläinen (1973) has given closer descriptions of the habitat preferences of studied species.

\subsection{Study area and sampling}

The samples were taken with a pond net from five localities ( 3 sites $<2 \mathrm{~km}, 2$ sites $>7 \mathrm{~km}$ from the factory, see Table 1). The two polluted sites were situated close to the iron and steel factory on a sea shore in Koverhar, Hanko Peninsula $\left(59^{\circ} 50^{`} \mathrm{~N}, 23^{\circ} 13^{`} \mathrm{E}\right.$ ) (see e.g. Heliövaara et al. 1982, Fritze 1991, Pankakoski et al. 1992, Monni \& Mäkinen 1995). The emissions of the Koverhar iron and steel factory were in 1994 according to the factory's official report (Fundia Wire 1995): $\mathrm{SO}_{2} 1175 \mathrm{t}, \mathrm{NO}_{\mathrm{x}} 554 \mathrm{t}$, dust $1193 \mathrm{t}$ (large part of this $\mathrm{Fe}$ ), and heavy metals $1.5 \mathrm{t}$ (only $\mathrm{As}, \mathrm{Cd}, \mathrm{Pb}, \mathrm{Zn}$ are included). In 1995, dust, $\mathrm{SO}_{2}$ and $\mathrm{NO}_{x}$ emissions decreased due to technical improvements in the factory. High concentrations of heavy metals have been measured close to the Koverhar iron and steel factory in small mammals (Pankakoski et al. 1994), pine needles (Hyle 1979), mosses (Rinne \& Mäkinen 1988), and from epiphyte lichens (Linden 1977,
Helminen et al. 1986, Holmberg 1989, 1992, Holmberg \& Pihlström 1992).

As unpolluted reference sites, Långskär island and Langis rivulet were used. Långskär island is situated ca. $7 \mathrm{~km} \mathrm{~S}$ from the factory (see e.g. Nummelin et al. 1984). Långskär is the outermost woody island in the Tvärminne archipelago, in the Northern Baltic Sea. Langis rivulet is situated in Täcktom ca. $7 \mathrm{~km} \mathrm{SW}$ from the factory. The collection site in Täcktom is adjacent to a road connecting Tvärminne village and Hanko town, having less than 10 cars/hour passing the site. Both Långskär and Täcktom are against the prevailing winds from the iron and steel factory.

The first samples were collected in June 1995. At that time of the year, the adults belong to overwintered population. The adults collected in August 1995 represent a generation which has hatched during the ongoing summer. Overwintered generation adults were collected between 19 and 21 June and the same summer generation samples were collected after 7 August (except one G. thoracicus V instar sample on 7 July).

The samples were divided according to sex, if there was enough material. In V-instar larvae, the sex was determined by the appearance of the genital segments with the aid of a binocular microscope. The main character referred to was the second last segment which is divided into two in females. Each analyzed sample consisted of 50-100 individuals.

\subsection{Chemical analysis}

All collected insects were first killed by deep freezing and dried at $+60^{\circ} \mathrm{C}$ in plastic tubes in a drying chamber for 10 hours and then stored at room temperature in plastic tubes. Before the chemical analysis, samples were dried ovemight at $105^{\circ} \mathrm{C}$. The animal samples were weighed in toto at an accuracy of $0.1 \mathrm{mg}$ to $0.5 \mathrm{~g}$ or less in glass test tubes and heated in $5 \mathrm{ml}$ of concentrated $\mathrm{HNO}_{3}(\mathrm{BDH}$, Aristar) for $2 \mathrm{~h}$ at $50^{\circ} \mathrm{C}$, and after that for $16-18 \mathrm{~h}$ at $110^{\circ} \mathrm{C}$. Five $\mathrm{ml}$ of $\mathrm{H}_{2} \mathrm{O}_{2}$ (Merck, p.a.) was added, and the samples were heated for an additional $6 \mathrm{~h}$. The samples were filtered and diluted with distilled water to $25 \mathrm{ml}$. Finally, the heavy metal concentrations ( $\mathrm{Al}, \mathrm{Cd}, \mathrm{Cu}, \mathrm{Fe}, \mathrm{Mn}, \mathrm{Ni}, \mathrm{Pb}, \mathrm{Zn}$ ) of sample solutions were analyzed with a flame atomic absorption spectrophotometer (Varian SpectrAA 400) or graphite furnace AAS (Varian SpectrAA 400 equipped with a GTA96). For the determination of $\mathrm{Al}, \mathrm{NaCl}$ was added to the sample solutions to make a concentration of at least $500 \mathrm{~g} / \mathrm{ml}$ of $\mathrm{Na}^{+}$and analyzed with a flame AAS (Perkin-Elmer 360). All the results are reported as concentrations in $\mu \mathrm{g} / \mathrm{g}$ of the dry weight.

\section{Results}

Water strider samples taken from close to the factory had higher heavy metal concentrations of all 
the other metals than $\mathrm{Cd}$ (see the end of the section for statistical differences). The average dry weight concentrations $(\mu \mathrm{g} / \mathrm{g})$ found near the factory were: $\mathrm{Al} \mathrm{76;} \mathrm{Fe} 844 ; \mathrm{Mn} \mathrm{49;} \mathrm{Zn} \mathrm{313;} \mathrm{Cu} \mathrm{44;}$ Cd 1.6; and in control areas: $\mathrm{Al} 65 ; \mathrm{Fe} 333 ; \mathrm{Mn}$ 37; $\mathrm{Zn} \mathrm{282;} \mathrm{Cu} 42 ; \mathrm{Cd} 6.5$. In most cases, $\mathrm{Ni}$ and $\mathrm{Pb}$ concentrations were below the determination limit in both sites (Table 1).

Canonical correspondence analysis on correlation matrix (Ter Braak 1988) was made based on heavy metal contents analyzed from water strider samples. The ordination diagram shows that water strider samples collected from near the iron and steel factory form their own group having very little overlap along the two canonical axes with the samples collected in control sites (two axes explain over $93 \%$ of total variance). G. odontogaster samples collected from near the factory mix with samples of other species collected from the control areas. On the other hand, in the ca-

Table 1. Heavy metal contents $(\mu \mathrm{g} / \mathrm{g})$ of Gerris lateralis, G. odontogaster, G. thoracicus and G. argentatus close to the Koverhar iron and steel factory and in the unpolluted control areas (* below the determination limit) (f: females, $\mathrm{m}$ : males, ad.: adults, $\mathrm{V}: \mathrm{V}$ instars, if sex is not indicated, sexes are combined in the sample) (Syn: Syndalsudden spring, $1 \mathrm{~km} \mathrm{~S}$ from the factory; Tvä: Tvärminne träsket $2 \mathrm{~km}$ SE from the factory; Lap: Lappvik bay, $1 \mathrm{~km}$ NW from the factory; Täc: Täcktom rivulet, $7 \mathrm{~km} \mathrm{SW}$ from the factory; Lån: Långskär island pools, $7 \mathrm{~km} \mathrm{~S}$ from the factory) (Jn: late June, Jl: early July, Au: early August).

\begin{tabular}{|c|c|c|c|c|c|c|c|c|c|c|}
\hline & & & Al & $\mathrm{Fe}$ & $\mathrm{Mn}$ & $\mathrm{Zn}$ & $\mathrm{Cu}$ & $\mathrm{Ni}$ & $C d$ & $\mathrm{~Pb}$ \\
\hline \multicolumn{11}{|c|}{ Close to the iron and steel factory } \\
\hline G.lat. ad. & Syn & Jn & 30 & 1160 & 80 & 400 & 50 & * & 1.5 & * \\
\hline G.lat. & Syn & $\mathrm{Au}$ & 105 & 1500 & 65 & 365 & 55 & * & 2.1 & * \\
\hline G.lat. m.ad. & Syn & $\mathrm{Au}$ & 60 & 1550 & 85 & 430 & 60 & * & 2.0 & * \\
\hline G.lat. f.V. & Syn & $\mathrm{Au}$ & 95 & 1500 & 55 & 315 & 50 & * & 1.6 & 0.6 \\
\hline G.lat. m.V. & Syn & $\mathrm{Au}$ & 50 & 1700 & 50 & 290 & 50 & * & 1.7 & 0.5 \\
\hline G.lat. f.ad. & Lap & $\mathrm{Au}$ & 70 & 620 & 45 & 320 & 45 & * & 1.9 & 0.6 \\
\hline G.lat. m.ad. & Lap & $\mathrm{Au}$ & 110 & 690 & 45 & 345 & 40 & * & 2.0 & 0.6 \\
\hline G.odo. ad. & Tvä & $\mathrm{Au}$ & 55 & 380 & 70 & 420 & 45 & * & 2.1 & * \\
\hline G.odo. ad. & Lap & $\mathrm{Au}$ & 120 & 310 & 35 & 300 & 40 & 0.7 & 1.7 & * \\
\hline G.tho. ad. & Lap & $J n$ & 80 & 520 & 35 & 280 & 40 & 0.6 & 0.96 & 0.5 \\
\hline G.tho. f.ad. & Lap & $\mathrm{Au}$ & 55 & 380 & 30 & 220 & 30 & * & 0.86 & * \\
\hline G.tho. m.ad. & Lap & $\mathrm{Au}$ & 40 & 440 & 30 & 235 & 35 & * & 0.91 & * \\
\hline G.tho. f.V. & Lap & $\mathrm{Au}$ & 100 & 540 & 30 & 225 & 35 & * & 1.1 & * \\
\hline G.tho. m.V. & Lap & $\mathrm{Au}$ & 90 & 530 & 30 & 235 & 35 & * & 1.4 & 0.5 \\
\hline Mean & & & 76 & 844 & 49 & 313 & 44 & - & 1.6 & - \\
\hline \multicolumn{11}{|l|}{ Control areas } \\
\hline G.lat. ad. & Täc & $\mathrm{Jn}$ & 40 & 620 & 125 & 470 & 45 & * & 3.8 & * \\
\hline G.lat. f.ad. & Täc & $\mathrm{Au}$ & 40 & 560 & 65 & 380 & 55 & * & 5.2 & * \\
\hline m.ad. & Täc & $\mathrm{Au}$ & 35 & 610 & 65 & 375 & 45 & * & 5.9 & * \\
\hline G.lat. & Täc & $\mathrm{Au}$ & 110 & 690 & 55 & 345 & 45 & * & 5.2 & * \\
\hline G.odo. f.ad. & Lån & $\mathrm{Au}$ & 65 & 170 & 25 & 310 & 40 & * & 12.4 & * \\
\hline G.odo. m.ad. & Lån & $\mathrm{Au}$ & 50 & 150 & 20 & 270 & 45 & * & 10.4 & * \\
\hline G.odo. V. & Lån & $\mathrm{Au}$ & 55 & 200 & 20 & 265 & 35 & * & 8.5 & * \\
\hline G.tho. f.ad. & Lån & $J n$ & 35 & 290 & 40 & 260 & 40 & * & 2.6 & 1.1 \\
\hline G.tho. m.ad. & Lån & $\mathrm{Jn}$ & 45 & 250 & 25 & 160 & 40 & * & 1.9 & 1.0 \\
\hline G.tho. f.ad. & Lån & $\mathrm{Au}$ & 70 & 250 & 25 & 230 & 30 & * & 7.6 & 0.5 \\
\hline G.tho. m.ad. & Lån & $\mathrm{Au}$ & 65 & 220 & 25 & 220 & 35 & * & 7.4 & * \\
\hline G.tho. f.V. & Lån & Jl & 75 & 360 & 20 & 235 & 45 & * & 3.3 & 0.5 \\
\hline G.tho. m.V. & Lån & ل ال & 70 & 350 & 20 & 225 & 45 & * & 3.1 & * \\
\hline G.arg. f.ad. & Lån & $\mathrm{Au}$ & 95 & 200 & 20 & 270 & 45 & * & 10.5 & * \\
\hline G.arg. m.ad. & Lån & $\mathrm{Au}$ & 90 & 190 & 20 & 255 & 45 & $\cdot$ & 9.1 & * \\
\hline G.arg. V & Lån & $\mathrm{Au}$ & 95 & 220 & 15 & 245 & 40 & 1.2 & 7.4 & 0.5 \\
\hline Mean & & & 65 & 333 & 37 & 282 & 42 & - & 6.5 & - \\
\hline
\end{tabular}




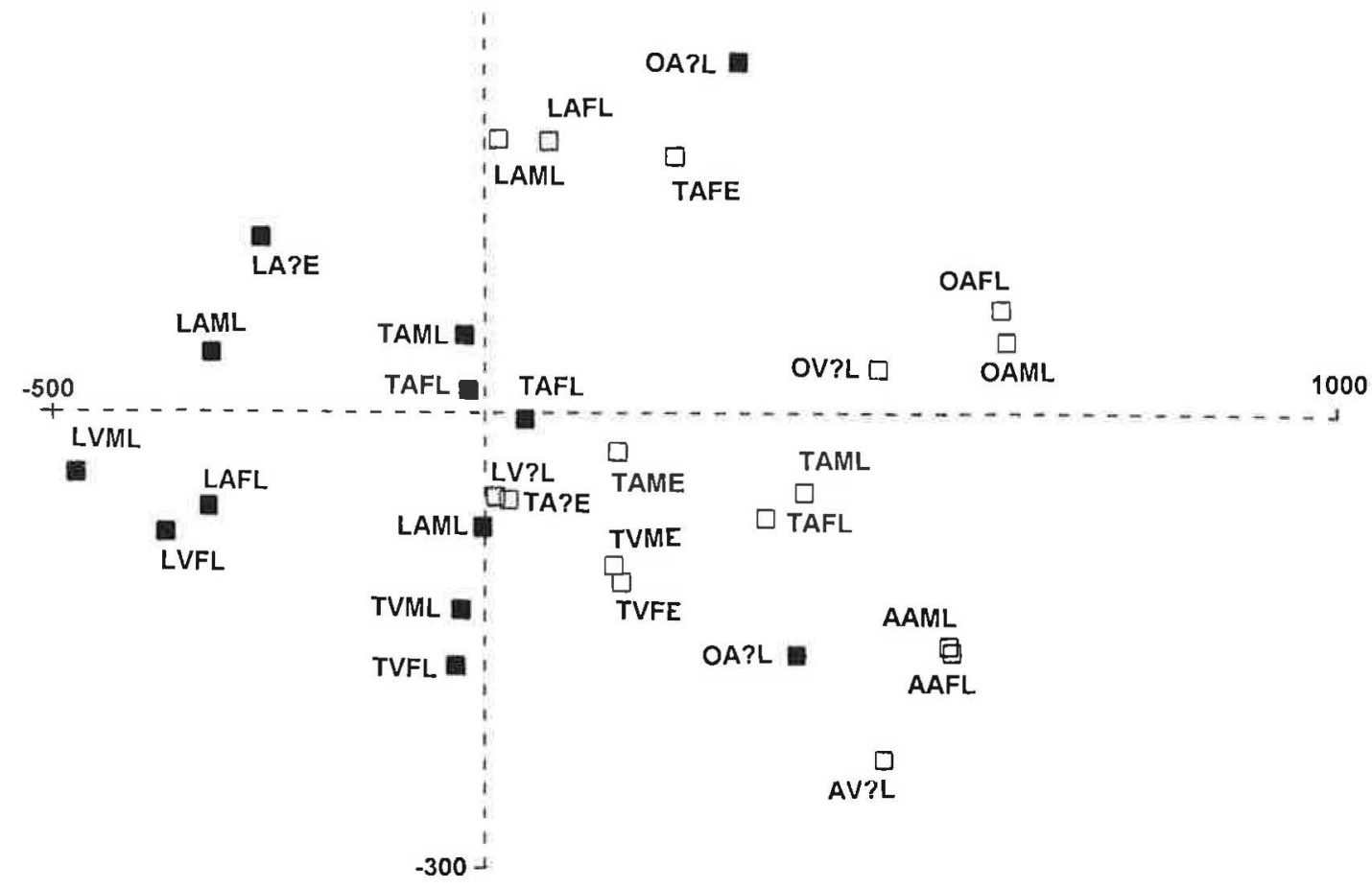

Fig. 1. Ordination diagram based on canonical correspondence analysis (correlation matrix) of the heavy metal concentrations in water strider samples from sites close to the Koverhar iron and steel factory and from a control site. Letters by each point indicate i) species: $A=G$. argentatus, $L=G$. lateralis, $O=G$. odontogaster, $T=G$. thoracicus; ii) developmental stage: $A=$ adult, $V=V$-instar larva; iii) sex: $F=$ female, $M=$ male, ? = undetermined; iv) sampling time: $E=$ early summer, $L=$ late summer. Samples close to the iron and steel factory are indicated with a black square.

nonical correspondence analysis ordination, G. odontogaster values from near the factory differ greatly from the ones collected in the control areas (Fig. 1).

In the analysis of the effect of the sampling site (less/over $2 \mathrm{~km}$ from the factory) on iron and cadmium, concentrations differed significantly ( $\mathbf{P}=0.001$, Sign test, species, sex, developmental stage and water strider generation constant). Iron concentrations were higher and cadmium concentrations lower in samples taken from close to the factory than those from the control sites.

Heavy metal concentrations did not differ significantly between the sexes in any species in pairwise comparisons (Sign test, distance from the factory, species, developmental stage and water strider generation constant).

The iron content of the developmental stages (adults vs. V-instar larvae) differed significantly. Adults had significantly less iron than larvae $(\mathrm{P}=$
0.008 , Sign test) in pairwise comparisons. There were no differences in other heavy metals between developmental stages (Sign test, distance to factory, species, sex and water strider generation were kept constant).

The efficiency of different species as accumulators of heavy metals was tested from samples taken in August from Långskär island. Since there was a significant difference between adults and $\mathrm{V}$-instars in iron content (see above), iron was omitted from species comparison. G. thoracicus accumulated significantly less zinc than $G$. argentatus and $G$. odontogaster $(\mathrm{t}=4.06, \mathrm{P}=0.01, \mathrm{df}=5$ for $G$. argentatus; $\mathrm{t}=-4.33, \mathrm{P}=0.008, \mathrm{df}=5$ for G. odontogaster, two-sample t-test). G. odontogaster accumulated significantly less aluminium than $G$. argentatus $(\mathrm{t}=7.78, \mathrm{P}=0.002$, $\mathrm{df}=4)$ and $G$. thoracicus $(\mathrm{t}=3.02, \mathrm{P}=0.029, \mathrm{df}=5)$. Also $G$. argentatus was more efficient in accumulating aluminium than $G$. thoracicus $(\mathrm{t}=8.37$, 


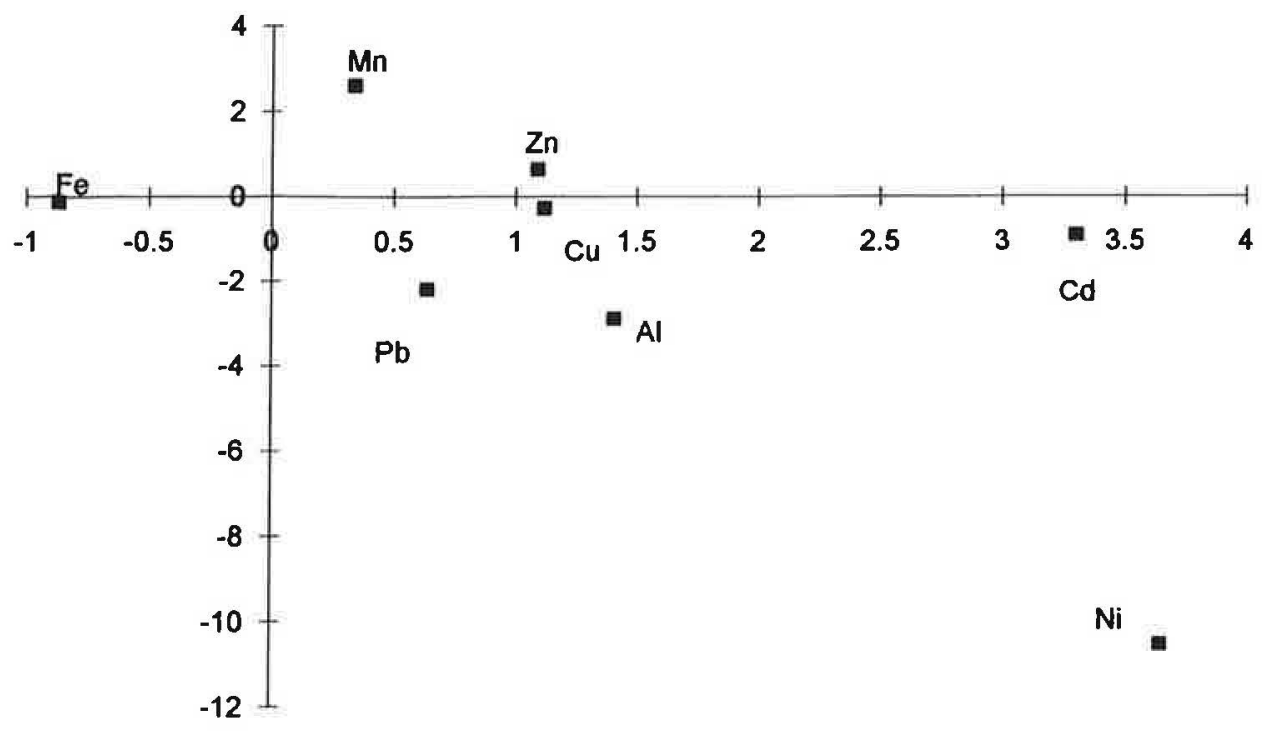

Fig. 2. Ordination diagram based on canonical correspondence analysis (correlation matrix) of the analyzed heavy metal concentrations in water strider samples.

$\mathrm{P}=0.0004, \mathrm{df}=5)$. . odontogaster accumulated significantly more cadmium than $G$. thoracicus $(\mathrm{t}=-2.91, \mathrm{P}=0.033, \mathrm{df}=5)$. All other specieswise comparisons in other heavy metal contents were statistically non-significant (two-sample ttest).

\section{Discussion}

Water striders seem to be efficient in accumulating cadmium, $\mathrm{Cd} 6.5 \mu \mathrm{g} / \mathrm{g}$ of dry weight found in in this study, compared with cadmium concentrations considered as high in Formicidae-ants (4$7 \mu \mathrm{g} / \mathrm{g}$ ) (Ylä-Mononen et al. 1989) and from spiders $(2-8 \mu \mathrm{g} / \mathrm{g}$ ) (Nuorteva et al. 1992). This study confirms the observations by Cheng et al. (1984) and Schulz-Baldes (1989) about the suitability of the water strider especially for cadmium indicators. The cadmium concentrations observed in this study are not as high as observed in sea-skaters in tropical oceans (over $100 \mu \mathrm{g} / \mathrm{g}$ ) (Cheng et al. 1976, Bull et al. 1977), but much higher than in Trichoptera larvae in acidificated lakes in Finland (0.5$2 \mu \mathrm{g} / \mathrm{g}$ ) (Verta et al. 1990). High Cd concentrations in sampled water striders may be partially explained by slightly higher $\mathrm{Cd}$ concentrations in stream sediments and stream water in the Hanko area than on average in Finland (Lahermo et al.
1995). Also, in the bed rock in the Hanko area, there are small zinc concentrations including cadmium (Raimo Lahtinen, Geological Survey of Finland, pers. comm.). This may also be the case for the bed rock and thus rock pools of Långskär.

This study did not detect any decline in the content of copper and lead with increasing distance from the factory. This type of decline has been detected in mosses in the same area (Rinne \& Mäkinen 1988).

In the canonical correspondence analysis, iron, cadmium and nickel seemed to separate each from the cluster of the rest of the heavy metals (Fig. 2). The difference in iron is easy to understand due to the proximity of the factory. Nickel contents were in most cases below the determination level explaining its separation. However, high values of cadmium in "undisturbed" sites require closer studies in the future.

There seems to be a tendency for females to have higher heavy metal contents than males, but the difference is not significant in this study. We hypothesize that the difference could be explained by higher food uptake of larger sized females than males. Additionally, females need more energy and thus food for egg production than males for sperm production. However, possible differences between sexes as heavy metal accumulators need further studies. 
V-instar larvae seem to have significantly higher iron contents than adults. The difference between developmental stages were not observed in the contents of the other heavy metals. Syndalsudd spring had a thick rusty sediment on its shallow bottom, and individuals caught in the net were often submerged to the sediment, thus causing external contamination.

G. lateralis populations sampled were almost totally wingless, thus adults originated from the sampling site. Adults in other studied species were winged and thus they may have arrived at the sampling sites from a distance. We believe that $G$. thoracicus adults taken from Lappvik bay in June are most prone to the latter in our samples.

According to the results, it seems that Finnish water striders are suitable as bioindicators for heavy metal studies.

Acknowledgments. We are indebted to Ali Soltanpour, D.Sc., for his valuable technical assistance. Comments by Satu Monni and unknown referees improved the manuscript.

\section{References}

Bull, K. R., Murton, R. K., Osborn, D., Ward, P. \& Cheng, L. 1977: High levels of cadmium in Atlantic seabirds and sea-skaters. - Nature, Lond. 269: 507-509.

Cheng, L., Alexander, G. V. \& Franco, P. J. 1976: Cadmium and other heavy metals in sea-skaters (Gerridae: Halobates, Rheumatobates). - Water Air Soil Pollution 6: 33-38.

Cheng, L., Schulz-Baldes, M. \& Harrison, C. S. 1984: Cadmium in ocean-skaters, Halobates sericeus (Insecta), and in their seabird predators. - Mar. Biol. 79: 321-324.

Clubb, R. W, Gaufin, A. R. \& Lords, J. 1975: Acute cadmium toxicity studies upon nine species of aquatic insects. - Environ. Res. 9: 332-341.

Fairbairn, D. J. 1986: Does alary dimorphism imply dispersal dimorphism in the waterstrider, Gerris remigis. Ecol. Entomol. 11: 355-368.

Fritze, H. 1991: Forest soil microbial response to emissions from an iron and steel works. - Soil Biol. Biochem. 23: $151-155$.

Fundia Wire Oy Ab 1995: Koverharin rauta- ja terästehtaan vuosiraportti vuodelta 1994. — Uudenmaan lääninhallitus, Helsinki.

Heliövaara, K., Terho, E. \& Koponen, M. 1982: Parasitism in the eggs of the pine bark-bug, Aradus cinnamomeus (Heteroptera, Aradidae). - Ann. Entomol. Fennica 48: 31-32.

Helminen, O., Laakso, M. \& Holmberg, R. 1986: Hangon ilmansuojelun perusselvitys 1985. — Länsi-Uuden- maan vesiensuojeluyhdistys r.y., Tutkimusjulkaisu 46: $1-60$.

Holmberg, R. 1989: Ilmansuojelun kasvillisuuskartoitus Hangossa 1988. — Länsi-Uudenmaan ilmansuojelu Oy $1-6$.

Holmberg, R. 1992: Hangon jäkälä- ja mäntyvauriokartoitus vuonna 1991. — Länsi-Uudenmaan vesi ja ympäristö r.y. 1-8.

Holmberg, R. \& Pihlström, M. 1992: Ilmansuojelun kasvillisuuskartoitukset Länsi-Uudellamaalla 1991. — LänsiUudenmaan vesi ja ympäristö r.y., Julkaisu 17: 1-22.

Hyle, M. 1979: Männynneulasten rikki- ja rautapitoisuus Koverharin rauta- ja terästehtaan ympäristössä I, 19711972. - Ovako Oy, Tutkimusselostus 166: 1-6.

Jamieson, G. S. \& Scudder, G. G. E. 1977: Food consumption in Gerris (Hemiptera), - Oecologia (Berl.) 30: 23-41.

Lahermo, P., Salminen, R., Tarvainen, T. \& Väänänen, P. 1995: Geochemical mapping of stream waters and sediments in Finland: Selected results. - Geological Survey of Finland, Spec. Pap. 20: 155-166.

Linden, C. 1977: Lavar och luftföroreningar på östra Hangöudd. - M.Sci.-thesis, Dept. Botany, Univ. He]sinki.

Linnavuori, R. 1966: Suomen eläimet, Animalia Fennica 10, Nivelkärsäiset I, Hemiptera I, Luteet 1, Hydrocoriomorpha, Amphibicoriomorpha ja Geocorisidae 1: Miridae. - WSOY, Porvoo. 205 pp.

Luther, A. 1993: Muurahaiset ympäristön tilan seurannassa: kirjallisuusselvitys ja ehdotus pilottitutkimukseksi (Ants in environmental monitoring). - Vesi ja ympäristöhallinnon julkaisuja, sarja A, 159. 35 pp. (In Finnish with English summary.)

Monni, S. \& Mäkinen, A. 1995: Ilman epäpuhtaudet ja niiden vaikutukset maaekosysteemeihin ja lähijärvien vedenlaatuun Oy Fundia Wire Ab:n Koverharin rauta ja terästehtaan ympäristössä Hankoniemellä vuosina 1959-1993, kirjallisuuskatsaus. - Department of Ecology and systematics, Ecology laboratory, Univ. Helsinki, Yliopistopaino, Helsinki, 114 pp. (Literature review in Finnish with English summary).

Nummelin, M., Vepsäläinen, K. \& Spence, J. 1984: Habitat partitioning among developmental stages of waterstriders (Heteroptera: Gerridae). — Oikos 42: 267-275.

Nuorteva, P., Nuorteva, S-L., Oja, A., Lehtinen, H. \& Salo, S. 1992: Two Achilles heels for metals in the Finnish forest ecosystem. - In: Boha, J. (ed.), Proc. VIth Int. Conf. Bioindicatores Deteriorisationis Regionis: 7277. Institute of Landscape Ecology, CAS, Ceske Budejovice.

Pankakoski, E., Koivisto, I., Hyvärinen, H. \& Terhivuo, J. 1994: Shrews as indicators of heavy metal pollution. — In: Merritt, J. F., Kirkland, G. L. Jr. \& Rose, R. K. (eds.), Advances in biology of shrews: 137-149. Carnagie Mus. Nat. Hist. Spec. Publ. 18.

Rao, D. A. \& Saxena, A. B. 1981: Acute toxicity of mercury, zinc, lead, cadmium, manganese to the Chironomus sp. - Int. J. Environ. Studies 16: 225-226.

Rinne, R. \& Mäkinen, A. 1988: Regional and species vari- 
ations in metal content of two woodland mosses Pleurozium schreberi and Hylocomium splendens in Finland and Northem Norway. — Silva Fennica 22: 89-97.

Schulz-Baldes, M. 1989: The sea-skater Halobates micans: An open ocean bioindicator for cadmium distribution in Atlantic surface waters. - Mar. Biol. 102: 211-215

Schulz-Baldes, M. \& Cheng, L. 1979: Uptake and loss of radioactive cadmium by the sea-skater Halobates robustus (Heteroptera: Gerridae). - Marine Biology 52: 253-258.

Spehar, R. L., Anderson, R. L. \& Fiandt, J. T. 1978: Toxicity and bioaccumulation of cadmium and lead in aquatic evertebrates. - Environ. Pollut. 15: 195-208.

Steinnes, E. 1989: Biomonitors of air pollution by heavy metals. - In: Ottar, B. \& Pacyna, J. (eds.), Control and fate of Atmospheric Heavy Metals: 321-328. Kluwer, Dordrecht.

Ter Braak, C. F. J. 1988: CANOCO - a FORTRAN program for canonical community ordination by correspondence analysis and redundancy analysis (version 2.1). - Groep landbouwwiskunde, Technical Report
LWA-88-02, Wageningen.

Vepsäläinen K. 1973: The distribution and habitats of Gerris Fabr. species (Heteroptera, Gerridae) in Finland. Ann. Zool. Fennici 10: 419-444.

Vepsäläinen, K. 1974: The life cycles and wing lengths of Finnish Gerris Fabr. species (Heteroptera, Gerridae). - Acta Zool. Fennica 141: 1-73.

Vepsäläinen, K. \& Krajewski, S. 1986: Identification of the waterstrider (Gerridae) nymphs of Northern Europe. - Ann. Entomol. Fennici 51: 45-49.

Verta, M., Mannio, J., Iivonen, P., Hirvi, J-P., Järvinen, O. \& Piepponen, S. 1990: Trace metals in Finnish headwater lakes. - In: Kauppi, P., Kenttämies, K. \& Anttila, P. (eds.), Acidification in Finland: 883-908. Springer Verlag.

Ylä-Mononen, L., Salminen, P., Wuorenrinne, H., Tulisalo, E. \& Nuorteva, P. 1989: Levels of Fe, Al, $\mathrm{Zn}$ and $\mathrm{Cd}$ in Formica aquilonia, F. polyctena and Myrmica ruginodis (Hymenoptera, Formicidae) collected in the vicinity of spruces showing different degrees of needle-loss. Ann. Entomol. Fenn. 55: 57-61. 